\title{
Effect of Gamma Irradiation on Growth and Lipid Productivity of Green Microalgae
}

Marwa M Moussa ${ }^{1^{\star}}$, Mervat AM Abo-state ${ }^{1}$, Ahmed AM Abdelhafez $^{2}$

1- Radiation Microbiology Dept, National Center of Radiation and Research Technology (NCRRT), Egyptian Atomic Energy Authority (EAEA), P.O. Box 29, Nasr City 11787, Cairo, Egypt

2- Agricultural Microbiology Dept, Faculty of Agriculture, Ain Shams University, P.O. Box 68, Hadayek Shoubra 11241, Cairo, Egypt

*Corresponding author: marwa.moussa@agr.asu.edu.eg

Received 14 September, 2020

Accepted 12 November, 2020

\section{Abstract}

In the present research, the impact of exposing Scenedesmus ecornis, S. communis, and Chlamydomonas $\mathrm{sp}$. cultures to doses of gamma irradiation on their growth and productivity of lipids was investigated. Biomass concentration $(\mathrm{g} / \mathrm{L}$ ) of each microalga was periodically determined after exposure to a range of gamma irradiation doses of 0,25 , $50,75,100,200$, and 300 Gray (Gy) through 20 days of cultivation. Subsequently, the lipid content (\%), and lipid productivity ( $\mathrm{mg} / \mathrm{L}$ day) of each species were evaluated. Results showed that the $S$. ecornis growth was positively affected by gamma irradiation, that the maximum concentration of biomass was obtained after 15 days at $1.3 \mathrm{~g} / \mathrm{L}$ by the irradiated S. ecornis exposed to a dose of $300 \mathrm{~Gy}$, while the non-irradiated culture achieved up to 1.1 $\mathrm{g} / \mathrm{L}$. On the other hand, the growths of Chlamydomonas sp. and $S$. communis were reduced significantly by the radiation treatment. Significant variations have been also observed in the content of lipid and lipid productivity of each microalga. Irradiated $S$. ecornis at a dose of 300 Gy exhibited the highest content of lipid and lipid productivity to reach $28.4 \%$ and $24.9 \mathrm{mg} / \mathrm{L}$ day, respectively. Conversely, the best yields of lipid content and lipid productivity were achieved by the non-irradiated culture of $S$. communis $(24.4 \%$ and $16.6 \mathrm{mg} / \mathrm{L}$ day, respectively), compared to irradiated culture, regardless of the irradiation dose. The highest lipid content and lipid productivity gained by Chlamydomonas $\mathrm{sp}$. were obtained by the cultures exposed to $25 \mathrm{~Gy}$, being $27.3 \%$ and $21.3 \mathrm{mg} / \mathrm{L}$ day, respectively. In conclu- sion, results indicated that exposing cells of $S$. ecornis and Chlamydomonas sp. to specific doses of gamma-rays has significantly stimulated lipid accumulation into cells, unlike $S$. communis which was negatively affected by gamma irradiation.

Keywords: Microalgae, Biomass concentration, Gamma irradiation, Lipid content, Lipid productivity

\section{Introduction}

Microalgae are a huge group that consists of diverse microscopic photosynthetic organisms characterized by high growth rates, simple cell structure, besides the flexibility of their metabolic behavior. Microalgal biomass is rich in valuable components like proteins, carbohydrates, pigments, and lipids; fatty acids and triglycerides that could be employed in several utilities including food, animal feed, therapeutics, cosmetics, and for biofuel production (e.g. hydrogen, methane, bioethanol, or biodiesel) (Williams and Laurens 2010, Qari et al 2017, Khan et al 2018, Raja et al 2018). Microalgae are considered as the major feedstock of biodiesel due to large lipid amounts that stored into their cells, besides limited requirements for arable soil, as compared to higher plants (e.g. jatropha) (Rawat et al 2011, Medipally et al 2015, Srikanth et al 2015, Tale et al 2018).

The content of lipids is the most significant factor employed to identify a microalgal species as a potential source of biodiesel, which is dependent on many parameters such as cell structure, growth phase, and cultivation conditions (Pal-Nath et al 2011, Lari et al 2016). However, the main concern 
in biodiesel biosynthesis from microalgae is the overall cost of a large-scale production. Various studies have been conducted to induce yield of lipids, and productivity of lipids into the microalgal biomass as key characteristics to select the microalgal species that is more suitable for producing biodiesel (Griffiths and Harrison 2009, Yang et al 2012). Previous efforts aimed to utilize several stress conditions, e.g. nutrients limitation, salinity, temperature, $\mathrm{CO}_{2}$ influence, heavy metals, and radiation to maximize the yield of lipids from the microalgal biomass (Sibi et al 2016, Rahman et al 2020). Among stress conditions, gamma irradiation could be employed to stimulate lipid accumulation into a microalgal cell (Ermavitalinia et al 2017, Liu et al 2015).

Gamma-ray (y-ray) is a form of ionizing radiation, which composed of high-energy penetrative photons. When y-ray is absorbed in the cell, it interacts directly with water molecules, and generates free radicals that can penetrate far enough causing either direct or indirect damage in DNA, breaking the chemical bonds, and damaging biomolecules involved in cell processes Fig 1. These effects may result in modifications in morphology, growth, and reproduction of microalgae (Kovàcs and Keresztes 2002, Dallas et al 2012, Jan et al 2012, Mohajer 2014, Jeong and Jeong 2018).

The influence of treatment by gamma irradiation primarily depends on the used dose, and the cell structure. At low doses of $\mathrm{Y}$-rays, cells may be slightly damaged, but sometimes they can also recover and return rapidly to their standard levels (Fuma et al 2009). While exposing cells to higher doses (more than $500 \mathrm{~Gy}$ ), may lead to irreversible damage and loss of the self-repair ability completely as a consequence of cell lysis (Kovàcs and Keresztes 2002, Agrawal et al 2008). As irradiation dose increases, cell metabolism and protein biosynthesis also decrease which may negatively affect the photosynthesis process by photoinhibition (Agrawal et al 2008, Jeong and Jeong 2018). Furthermore, the biochemical reactions into cells may also positively affected by gamma irradiation treatment resulted in enhancing the accumulation of some bioactive molecules (e.g. lipids, proteins, and carbohydrates) (Abomohra et al 2016). As well, Tale et al (2018) reported that gamma irradiation treatment may also lead to a remarkable rise in the expression of regulatory genes that are basically involved in the biosynthesis of lipids like diacyl-glycerol acyl-transferase and acetyl-CoA carboxylase, and consequently the accumulation of lipids into microalgal cells has increased.
Furthermore, lipids contents of other biological materials may positively be affected by gamma irradiation. For instance, Afify et al (2013) stated that exposing seeds of sesame, peanut, and soybean to gamma irradiation has created significant changes in the composition of lipids extracted from gamma irradiated seeds compared to non-irradiated seeds. However, the reports focusing on the impact of Y-rays on microalgae are limited. Accordingly, this investigation was designed to follow up the impact of gamma irradiation treatment on the subsequent production biomass and total lipids of three green microalgae; Scenedesmus ecornis, S. communis, and Chlamydomonas sp. in order to induce the lipid content and productivity which will be used afterward for biodiesel production.

\subsection{Species of microalgae and the cultivation conditions}

Three cultures of fresh water green microalgae; namely Scenedesmus ecornis, S. communis (Family: Scenedesmaceae), and Chlamydomonas sp. (Family: Chlamydomonadaceae), were obtained from the Lammi biological station, University of Helsinki, Finland. The three microalgae were cultured in the modified WC (MWC) medium which contains the following stock solutions $(\mathrm{g} / \mathrm{L})$ : [1] $\mathrm{CaCl}_{2} \cdot 2 \mathrm{H}_{2} \mathrm{O}$ (36.76), [2] $\mathrm{K}_{2} \mathrm{HPO}_{4} \cdot 3 \mathrm{H}_{2} \mathrm{O}$ (8.71), [3] $\mathrm{MgSO}_{4} \cdot 7 \mathrm{H}_{2} \mathrm{O}$ (36.76), [4] $\mathrm{NaHCO}_{3}$ (12.6), [5] $\mathrm{Na}_{2} \mathrm{O}_{3} \mathrm{Si} \cdot 5 \mathrm{H}_{2} \mathrm{O}$ (28.42), [6] $\mathrm{NaNO}_{3}$ (85.01), [7] Trace-elements stock solution (g/L): $\mathrm{CoCl}_{2} \cdot 6 \mathrm{H}_{2} \mathrm{O} \quad(0.011)$, $\mathrm{CuSO}_{4} \cdot 5 \mathrm{H}_{2} \mathrm{O}$ (0.011), $\mathrm{FeCl}_{3} \cdot 6 \mathrm{H}_{2} \mathrm{O}$ (3.15), $\mathrm{H}_{3} \mathrm{BO}_{3}$ (1.00), $\quad \mathrm{MnCl}_{2} \cdot 4 \mathrm{H}_{2} \mathrm{O}$ (0.18), $\mathrm{Na}_{2}$ EDTA (4.36), $\mathrm{Na}_{2} \mathrm{MoO}_{4} \cdot 2 \mathrm{H}_{2} \mathrm{O}(0.01)$, and $\mathrm{ZnSO}_{4} \cdot 7 \mathrm{H}_{2} \mathrm{O}(0.022)$, [8] Vitamin-mix stock solution (g/L): Biotin (0.0005), Cyanocobalamin (0.0005), and Thiamine-HCL (0.1), and [9] TES buffer (0.115 g/L) (Guillard and Lorenzen 1972).

\section{Materials and Methods}

The MWC medium was initially prepared by the addition of $1.0 \mathrm{~mL}$ of the above-mentioned stock solutions [1-8], and also $0.115 \mathrm{~g}$ of TES buffer to 1.0 liter of the purified water. $\mathrm{pH}$ was adjusted to $7.50 \pm$ 0.20 and the medium was autoclaved afterward at $121^{\circ} \mathrm{C} / 20 \mathrm{~min}$. MWC medium was inoculated with a 7-day old culture of each microalga at the ratio of $10 \%(v / v)$. The initial inoculum concentrations for $S$. ecornis, S. communis, and Chlamydomonas sp. were up to $0.24,0.23$, and $0.19 \mathrm{~g} / \mathrm{L}$, respectively. All microalgal cultures were incubated at $25^{\circ} \mathrm{C}$, under a continuous illumination of $100 \mu$ mole photons $/ \mathrm{m}^{2} \mathrm{~s}$ for 7 days (the exponential phase of growth). 


\section{Effect of gamma irradiation on growth and lipid productivity of green microalgae}

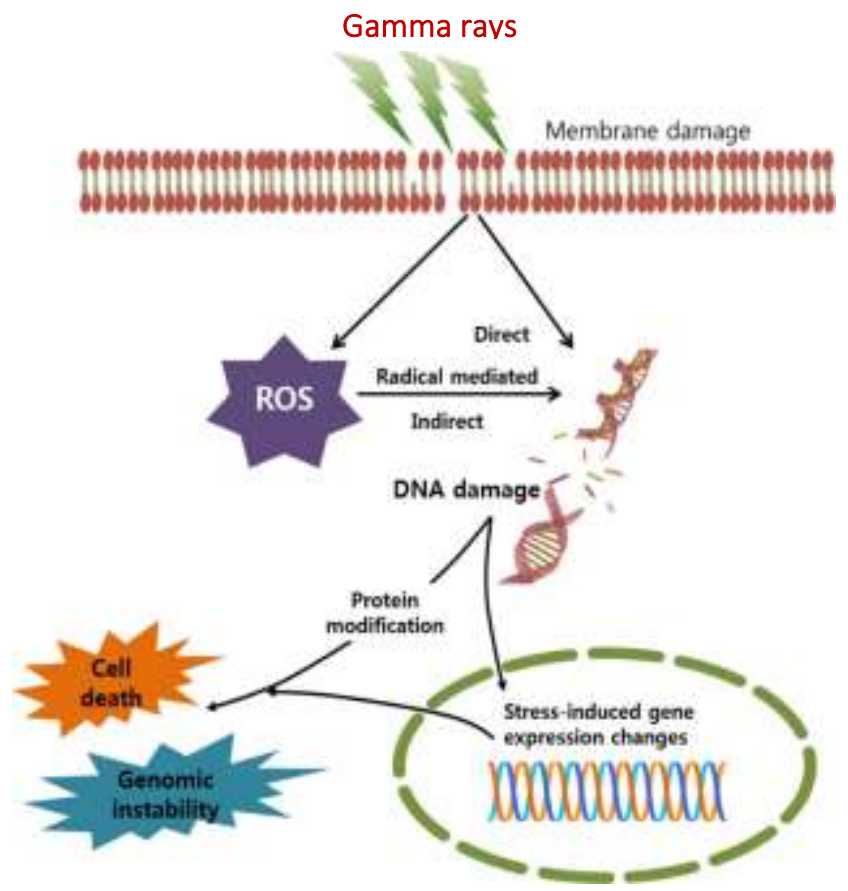

Fig 1. Direct and indirect effects of gamma radiation on DNA (Jeong and Jeong 2018)

\subsection{Treatment of the microalgal cultures by gamma irradiation}

Each microalgal culture was exposed to different $\mathrm{y}$-rays doses to examine the impact of each dose on the production of biomass and lipids by microalga. Each culture of microalga was firstly distributed into the screw-cap test tubes (10 mL/ tube) and exposed to Y-rays at doses of $0,25,50,75,100$, 200 , and 300 Gy. Gamma irradiation treatment was carried out using the Indian ${ }^{60} \mathrm{Co}$-gamma irradiation cell (NCRRT, EAEA, Cairo, Egypt). The dose rate was at $18.65 \mathrm{~Gy} / \mathrm{min}$, at the time of the experiment. Irradiated cultures were cultivated on MWC agar plates and the grown colonies were counted after a few days. The survival rates were calculated using the subsequent equation:

$$
\text { Survival rate }(\%)=\frac{\text { Cell count after radiation }(\mathrm{CFU} / \mathrm{mL})}{\text { Cell count before radiation }(\mathrm{CFU} / \mathrm{mL})} \times
$$

The survived cells were inoculated into $10 \mathrm{~mL}$ of a liquid medium of MWC placed in screw-cap tubes (Choi et al 2014). These tubes were then used to inoculate Erlenmeyer-flasks containing $200 \mathrm{~mL}$ of MWC medium at a ratio of $10 \%(\mathrm{v} / \mathrm{v})$ and then incubated at $25^{\circ} \mathrm{C}$, under a continuous illumination of $100 \mu$ mole photons $/ \mathrm{m}^{2} \mathrm{~s}$ for 20 days. Biomass concentration, the content of lipids, and the productivity of biomass and lipids for each microalga were analyzed, as described later.

\subsubsection{Determination of microalgal growth}

The growth of microalga was monitored by measuring the dry weight of biomass $(\mathrm{g} / \mathrm{L})$ of irradiated and non-irradiated microalgae. The biomass was periodically harvested by a centrifugation of a sample (100 mL of the microalgal culture) at 4000 rpm/ $10 \mathrm{~min}$ (Cheng et al 2014). The pellet was carefully rinsed with the purified water then dried at $60^{\circ} \mathrm{C}$ to constant weight. Biomass concentration was periodically determined and the biomass productivity ( $P$ Biomass) was estimated via the equation:

$$
P_{\text {Biomass }}(\mathrm{mg} / \mathrm{L} \text { day })=\frac{\text { Biomass concentration }(\mathrm{mg} / \mathrm{L})}{\text { Cultivation period }(\text { day })}
$$

\subsubsection{Extraction of total lipids and determination of the content of lipids and productivity}

The influence of a variety of gamma irradiation doses on the content and productivity of lipids of each microalga was tested in order to choose the best exposure dose for each microalga which enhances lipid productivity after a period of cultivation. 
Microalgal biomass was collected as previously described, vortexed with $2.0 \mathrm{~mL}$ of $1.50 \mathrm{M} \mathrm{NaCl}$ solution for $2 \mathrm{~min}$, and then kept at room temperature for $48 \mathrm{~h}$ (for cell disruption). Extraction of lipids was conducted using a single-step extraction approach by a chloroform and methanol mixture $(2: 1 \mathrm{v} / \mathrm{v})$, according to Axelsson and Gentili (2014). Then, the organic phase was carefully collected in a pre-weighed vial, and the organic solvent was evaporated at $30 \stackrel{\circ}{ }$. For each microalga, the total lipids content was determined and expressed as the ratio of the wet weight of biomass (Choi et al 2014). Lipid content ( $\left.\mathrm{C}_{\text {Lipid }}\right)$ and productivity $\left(\mathrm{P}_{\text {Lipid }}\right)$ were calculated via the subsequent equations:

$$
\begin{gathered}
\mathrm{C}_{\text {Lipid }}(\%)=\frac{\text { Lipid weight }(\mathrm{mg} / \mathrm{L})}{\text { Biomass concentration }(\mathrm{mg} / \mathrm{L})} \times 100 \\
\mathrm{P}_{\text {Lipid }}(\mathrm{mg} / \mathrm{L} \text { day })=\frac{\mathrm{C}_{\text {Lipid }}(\%) \times \mathrm{P}_{\text {Biomass }}(\mathrm{mg} / \mathrm{L} \text { day })}{100}
\end{gathered}
$$

\subsection{Statistical analysis}

Data were expressed as mean of three replicates \pm standard deviation (S.D.). Statistical analysis of data was performed via using SPSS software v. 16.0 and data were analyzed with One-way analysis of variance (ANOVA), with $p$-values lower than 0.05 being considered as significant. Differences between the means were compared using Tukey's honestly significant differences (HSD) test.

\section{Results and Discussion}

\subsection{Survival rates of microalgae}

As presented in Table 1, the survival rates (\%) of $S$. ecornis, $S$. communis, and Chlamydomonas $\mathrm{sp}$. were significantly affected by an exposure dose of y-rays. The three microalgae; Chlamydomonas sp., S. ecornis, and S. communis, have exhibited the highest survival rates at an absorbed dose of 25 Gy $(75.6 \%, 70.9 \%$, and $77.2 \%$, respectively). At relative higher irradiation doses, the rates of survival cells were slightly reduced, to reach lower levels at 300 Gy for all three microalgae.

\subsection{Impact of different gamma irradiation doses on the microalgal growth}

In the present investigation, the cultures of $S$. ecornis, S. communis, and Chlamydomonas sp. were exposed to a variety of gamma irradiation doses $(0,25,50,75,100,200$ and $300 \mathrm{~Gy})$ to investigate the effect of $\mathrm{y}$-rays on their growth. Biomass concentrations ( $\mathrm{g} / \mathrm{L}$ ) of both non-irradiated and irradiated microalgae were compared, as outlined in Figs 2-4.
Exposing S. ecornis to gamma irradiation has a positive effect on its growth Fig 2, that the growth of irradiated $S$. ecornis was higher than the non-irradiated microalga. Results showed that after 15 days of cultivation, the growth of $S$. ecornis culture exposed to 300 Gy was $1.32 \mathrm{~g} / \mathrm{L}$, followed by $1.22 \mathrm{~g} / \mathrm{L}$ and $1.20 \mathrm{~g} / \mathrm{L}$ by irradiated cultures at doses of 100 and $75 \mathrm{~Gy}$, respectively. Whereas the maximum growth amount of the non-irradiated culture was $1.10 \mathrm{~g} / \mathrm{L}$.

Unlike, S. communis has responded differently to gamma irradiation, as illustrated in Fig 3, where the growth of irradiated microalgae decreased slightly compared to the non-irradiated culture. The highest concentration of biomass $(1.02 \mathrm{~g} / \mathrm{L})$ was recorded by non-irradiated culture after 15 days of the cultivation period. The biomass production has been reduced with the increase of irradiation dose from $0.89 \mathrm{~g} / \mathrm{L}$ at $25 \mathrm{~Gy}$ to $0.76 \mathrm{~g} / \mathrm{L}$ at $300 \mathrm{~Gy}$.

In comparison to the non-irradiated Chlamydomonas sp. growth, a slight reduction has occurred in the growth of irradiated microalgae correlated to irradiation dose, as illustrated in Fig 4. The highest concentration of biomass obtained by non-irradiated Chlamydomonas sp. was $1.27 \mathrm{~g} / \mathrm{L}$, while biomass concentration of irradiated microalgae has continued to decline as the dose increases until reaching the minimum levels up to 0.96 and $0.92 \mathrm{~g} / \mathrm{L}$ at doses of 200 and 300 Gy, respectively.

From the foregoing results, it could be concluded that gamma irradiation has significantly enhanced the growth of $S$. ecornis while a slight decrease in the growth of both $S$. communis and Chlamydomonas sp. was observed. This could be explained that the effect of irradiation treatment mainly based on each species of microalgae. For example, a rise in $S$. ecornis growth is probably due to its resistance to the tested doses which indicates the efficiency of the repair system of DNA.

Choi et al (2014) have also demonstrated that exposing Scenedesmus dimorphus to irradiation dose of 800 Gy has induced the expression of lipid biosynthesis-associated proteins, namely hydroxy methyltransferase. This enzyme can stimulate the accumulation of lipids within the cytoplasm and chloroplast, which might improve the tolerance to oxidative stress and resistance of the microalga (Garay et al 2014; Zhu et al 2016). As obtained by Golz and Bradshaw (2019), that the growth of Spirulina platensis has significantly increased at lower gamma irradiation doses (less than 500 Gy) while at higher doses, its growth was inhibited by $30 \%$. Although, exposing the microalgal cells to gamma irradiation might also lead to biomass loss 

of green microalgae

Table 1. Survival rates (\%) of Chlamydomonas sp., S. ecornis and S. communis after being exposed to different gamma irradiation doses

\begin{tabular}{|c|c|c|c|}
\hline \multirow{2}{*}{$\begin{array}{c}\text { Irradiation dose } \\
\text { (Gy) }\end{array}$} & \multicolumn{3}{|c|}{ Survival rate (\%) } \\
\cline { 2 - 4 } & Chlamydomonas sp. & S. ecornis & S. communis \\
\hline 25 & $77.2 \pm 0.5^{\mathrm{a}}$ & $75.6 \pm 0.6^{\mathrm{a}}$ & $70.5 \pm 0.4^{\mathrm{a}}$ \\
$\mathbf{5 0}$ & $73.0 \pm 0.7^{\mathrm{b}}$ & $69.0 \pm 1.8^{\mathrm{b}}$ & $66.0 \pm 1.3^{\mathrm{b}}$ \\
$\mathbf{7 5}$ & $68.4 \pm 1.1^{\mathrm{c}}$ & $62.4 \pm 0.0^{\mathrm{c}}$ & $64.8 \pm 2.1^{\mathrm{bc}}$ \\
$\mathbf{1 0 0}$ & $63.8 \pm 0.0^{\mathrm{cd}}$ & $59.3 \pm 0.3^{\mathrm{d}}$ & $59.1 \pm 0.9^{\mathrm{d}}$ \\
$\mathbf{2 0 0}$ & $57.1 \pm 0.1^{\mathrm{e}}$ & $54.4 \pm 0.5^{\mathrm{de}}$ & $56.3 \pm 1.0^{\mathrm{de}}$ \\
300 & $53.3 \pm 0.5^{\dagger}$ & $51.7 \pm 1.2^{\mathrm{e}}$ & $48.4 \pm 0.7^{\dagger}$ \\
\hline
\end{tabular}

1 Data were expressed as means \pm S.D., $\mathrm{n}=3$.

Values with the same letter(s) are insignificantly different at $p$-value $<0.01$ (Tukey's HSD test).

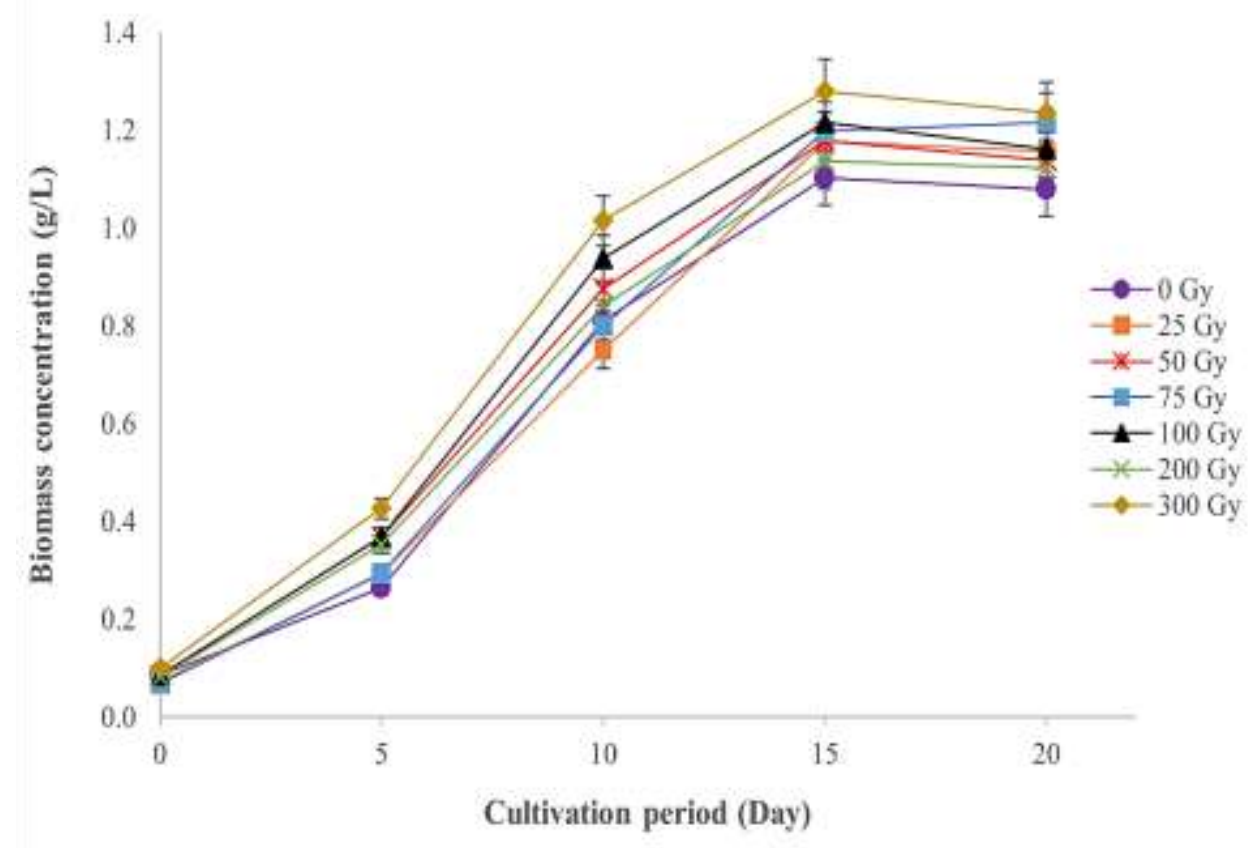

Fig 2. Effect of different gamma irradiation doses on the $S$. ecornis growth (error bars represent S.D., $\mathrm{n}=3$, p-value <0.01) 


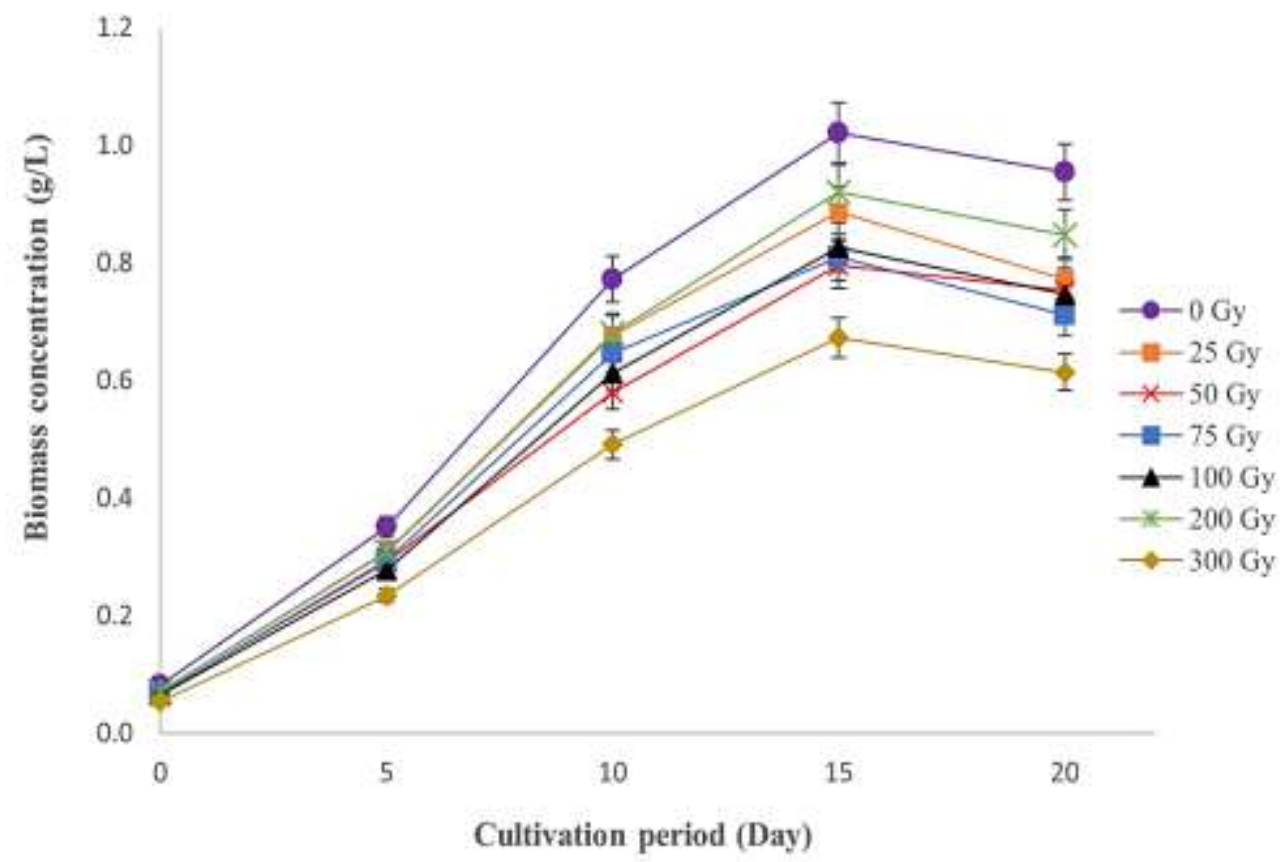

Fig 3. Effect of different gamma irradiation doses on the $S$. communis growth (error bars represent S.D. of triplicates, $p$-value $<0.05$ )

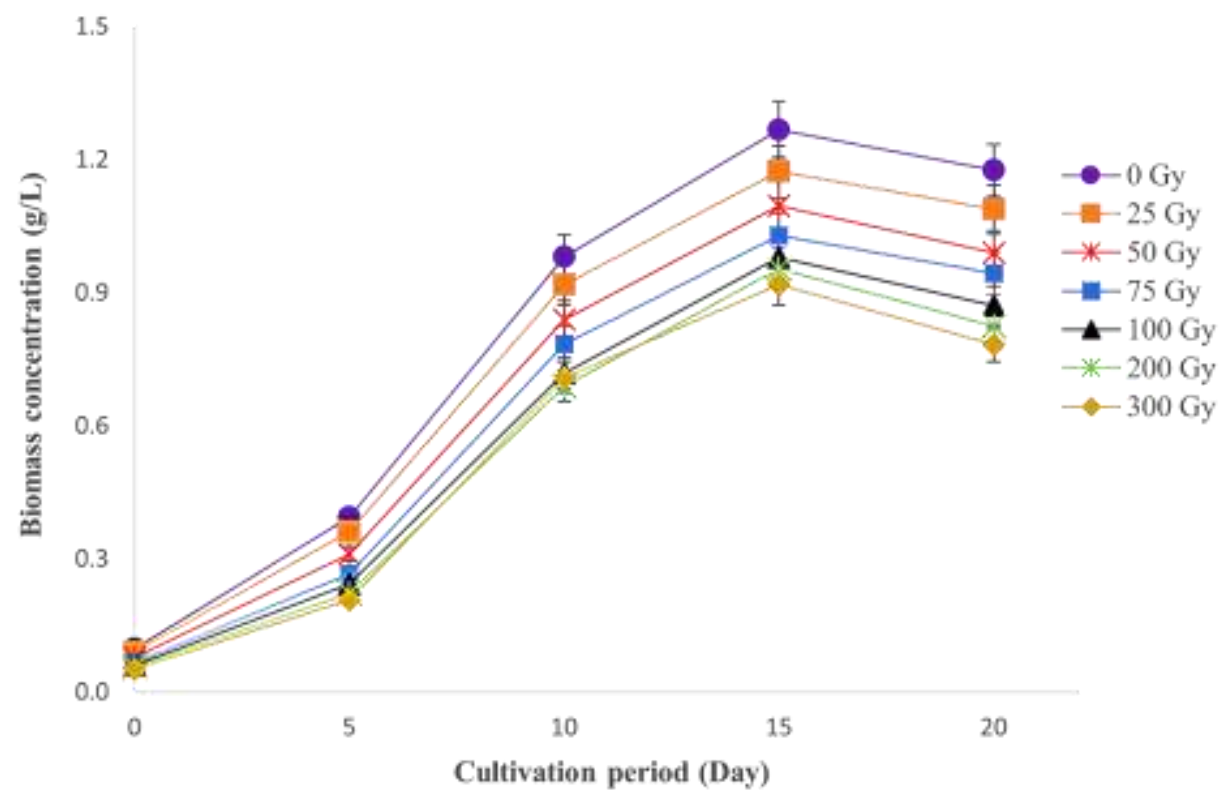

Fig 4. Effect of different gamma irradiation doses on the Chlamydomonas sp. growth (error bars represent S.D. of triplicates, $p$-value $<0.02$ ) 
occasionally as in the case of $S$. communis and Chlamydomonas sp. (Griffiths and Harrison 2009). Another study by Abomohra et al (2016) revealed that even though the gamma irradiation had an adverse impact on the biomass production of Spirulina platensis, a significant rise in the carbohydrates, lipids, and pigments amounts was observed in biomass extracts, unlike the protein levels.

Accordingly, the determination of both lipid content and productivity of microalga was required after irradiation to select the most efficient dose in stimulating the accumulation of lipid into the microalgal cell.

\subsection{Effect of gamma irradiation doses on the lipid content and productivity of microalgae}

To follow up the gamma irradiation effect on the lipid content (CLipid) and productivity (PLipid) of $S$. ecornis, S. communis, and Chlamydomonas sp., lipids contents were determined after 15 days of cultivation and data are shown in Tables 2-4.

Data presented in Table 2 showed that lipid content and productivity of irradiated $S$. ecornis have significantly increased by different doses of y-rays, compared to the non-irradiated culture. The highest yield of lipid (28.4\%), biomass productivity (87.6 $\mathrm{mg} / \mathrm{L}$ day), and lipid productivity $(24.9 \mathrm{mg} / \mathrm{L}$ day) were all achieved by gamma irradiated $S$. ecornis at $300 \mathrm{~Gy}$. As for the non-irradiated microalga, the minimal values of lipid yield, biomass productivity, and lipid productivity were equal to $25.2 \%, 71.8$ $\mathrm{mg} / \mathrm{L}$ day, and $18.5 \mathrm{mg} / \mathrm{L}$ day, respectively.

The non-irradiated culture of $S$. communis found to produce higher levels of lipids more than the obtained from the gamma irradiated microalga regardless of the absorbed dose Table 3 . The levels of lipid content and biomass and lipid productivities were slightly reduced by the increase in a dose of irradiation, due to the biomass loss resulting from gamma irradiation treatment. The highest level of lipid content and biomass and lipid productivities were $24.4 \%$ and $68.1 \mathrm{mg} / \mathrm{L}$ day and $16.6 \mathrm{mg} / \mathrm{L}$ day, respectively for the non-irradiated microalga.
Whereas the minimum content of lipids (19.9\%) was recorded by the irradiated $S$. communis at $300 \mathrm{~Gy}$ with lipid productivity up to $10.1 \mathrm{mg} / \mathrm{L}$ day, and biomass productivity of $50.7 \mathrm{mg} / \mathrm{L}$ day.

From results expressed in Table 4, even though the productivity of biomass of Chlamydomonas sp. was declined by irradiation treatment, the levels of lipid content and productivity have significantly improved at the lowest dose (25 Gy). The highest content of lipids and lipid productivity $(27.3 \%$ and 21.3 $\mathrm{mg} / \mathrm{L}$ day, respectively) were obtained by irradiated microalga at 25 Gy with a productivity of biomass of $78.2 \mathrm{mg} / \mathrm{L}$ day. On the other hand, the highest biomass productivity was at $84.5 \mathrm{mg} / \mathrm{L}$ day for the non-irradiated Chlamydomonas sp. along with $19.8 \%$ and $23.4 \mathrm{mg} / \mathrm{L}$ day for lipid contents, and lipid productivity, respectively. While the minimum content of lipids (18.1\%), productivity of biomass (61.2 $\mathrm{mg} / \mathrm{L}$ day), and productivity of lipids ( $11.1 \mathrm{mg} / \mathrm{L}$ day) were recorded by irradiated microalga at $300 \mathrm{~Gy}$.

These findings might be attributed to slight oxidative stress caused by the treatment of gamma irradiation of microalgal species at low doses that led to enhance lipid biosynthesis and therefore increase the lipid accumulation in cells were obtained by irradiated Chlamydomonas sp. and S. ecornis cultures at doses of 25 and 300 Gy, respectively (Tale et al 2018). In a similar investigation, Choi et al (2014) revealed that inducing a mutant strain ( $\mathrm{Sd}-\mathrm{Pm} 210)$ was performed by exposing $S$. dimorphus to a gamma irradiation dose of $800 \mathrm{~Gy}$. The Sd-Pm 210 mutant showed significantly higher levels of total lipids than obtained by the wild-type. In the same context, Abomohra et al (2016) stated that exposing the cells of Spirulina platensis to 500 Gy dose has significantly enhanced the lipid yield by $22.0 \%$ more than the non-irradiated microalga, unlike the higher doses that caused a considerable drop in the content of intracellular lipids. In contrast, Abo-State et al (2019) revealed that the gamma irradiation treatment has considerably reduced the yield of lipids from the irradiated Chlorella vulgaris in contrast to the non-irradiated culture which exhibited the maximum content of lipid. 
Table 2. Effect of different gamma irradiation doses on lipid content (\%), biomass, and lipid productivity (mg/L day) of $S$. Ecornis after a cultivation period of 15 days

\begin{tabular}{|c|c|c|c|}
\hline $\begin{array}{c}\text { Irradiation dose } \\
\text { (Gy) }\end{array}$ & $\begin{array}{c}\text { Lipid content }^{\mathbf{1}} \\
\text { (\%) }^{\boldsymbol{*}}\end{array}$ & $\begin{array}{c}\text { Biomass productivity } \\
\text { ( } \mathbf{m g} / \mathbf{L} \text { day) }\end{array}$ & $\begin{array}{c}\text { Lipid productivity }^{\mathbf{3}} \\
\text { (mg/L day) }\end{array}$ \\
\hline 0 & $25.2 \pm 0.1^{\mathrm{c}}$ & $71.8 \pm 2.8^{\mathrm{g}}$ & $18.5 \pm 1.5^{\mathrm{d}}$ \\
25 & $27.2 \pm 04^{\mathrm{b}}$ & $74.2 \pm 1.0^{\mathrm{e}}$ & $20.2 \pm 0.8^{\mathrm{c}}$ \\
50 & $27.1 \pm 1.8^{\mathrm{b}}$ & $75.1 \pm 1.2^{\mathrm{d}}$ & $20.4 \pm 2.4^{\mathrm{c}}$ \\
75 & $27.5 \pm 1.2^{\mathrm{b}}$ & $77.4 \pm 0.3^{\mathrm{b}}$ & $21.3 \pm 0.3^{\mathrm{b}}$ \\
100 & $27.0 \pm 0.6^{\mathrm{b}}$ & $76.1 \pm 0.6^{\mathrm{c}}$ & $20.6 \pm 1.2^{\mathrm{c}}$ \\
200 & $27.5 \pm 0.6^{\mathrm{b}}$ & $73.1 \pm 3.3^{\mathrm{f}}$ & $20.1 \pm 0.7^{\mathrm{c}}$ \\
300 & $28.4 \pm 1.1^{\mathrm{a}}$ & $87.8 \pm 1.7^{\mathrm{a}}$ & $24.9 \pm 0.8^{\mathrm{a}}$ \\
\hline
\end{tabular}

$\mathrm{C}_{\text {Lipid }}=[$ Lipid weight $\div$ Biomass concentration $] \times 100$

$\mathrm{P}$ Biomass $=$ Biomass concentration $\div$ Cultivation period

$\mathrm{P}_{\text {Lipid }}=\left[\mathrm{C}_{\text {Lipids }} \times \mathrm{P}_{\text {biomass }}\right] \div 100$

4 Data were expressed as means \pm S.D., $\mathrm{n}=3$.

5 Values with the same letter(s) are insignificantly different at p-value $<0.05$ (Tukey's HSD test).

Table 3. Effect of different gamma irradiation doses on lipid content (\%), biomass, and lipid productivity (mg/L day) of $S$. communis after a cultivation period of 15 days

\begin{tabular}{|c|c|c|c|}
\hline $\begin{array}{c}\text { Irradiation dose } \\
\text { (Gy) }\end{array}$ & $\begin{array}{c}\text { Lipid content }{ }^{1} \\
(\%)\end{array}$ & $\begin{array}{c}\text { Biomass productivity }{ }^{2} \\
\text { (mg/L day) }\end{array}$ & $\begin{array}{l}\text { Lipid productivity } \\
\text { (mg/L day) }\end{array}$ \\
\hline 0 & $24.4 \pm 0.8^{a}$ & $68.1 \pm 2.3^{a}$ & $16.6 \pm 0.1^{\mathrm{a}}$ \\
\hline 25 & $22.6 \pm 1.0^{\mathrm{b}}$ & $59.2 \pm 1.1^{\mathrm{b}}$ & $13.4 \pm 0.7^{b}$ \\
\hline 50 & $22.1 \pm 1.3^{b}$ & $53.1 \pm 0.4^{e}$ & $11.7 \pm 0.2^{\mathrm{c}}$ \\
\hline 75 & $21.7 \pm 0.6^{c}$ & $54.0 \pm 0.2^{\mathrm{d}}$ & $11.7 \pm 1.6^{c}$ \\
\hline 100 & $21.0 \pm 0.2^{\mathrm{d}}$ & $55.3 \pm 0.7^{c}$ & $11.6 \pm 0.9^{c}$ \\
\hline 200 & $20.5 \pm 2.1^{d}$ & $55.5 \pm 1.8^{c}$ & $11.4 \pm 0.3^{c}$ \\
\hline \begin{tabular}{l|l}
300 \\
\end{tabular} & $19.9 \pm 0.4^{\mathrm{e}}$ & $50.7 \pm 0.6^{f}$ & $10.1 \pm 2.5^{d}$ \\
\hline \multicolumn{4}{|c|}{$\mathrm{C}_{\text {Lipid }}=[$ Lipid weight $\div$ Biomass concentration $] \times 100$} \\
\hline \multicolumn{4}{|c|}{$2 \quad \mathrm{P}_{\text {Biomass }}=$ Biomass concentration $\div$ Cultivation period } \\
\hline \multicolumn{4}{|c|}{$3 \quad P_{\text {Lipid }}=\left[C_{\text {Lipids }} \times P_{\text {biomass }}\right] \div 100$} \\
\hline \multicolumn{4}{|c|}{4 Data were expressed as means } \\
\hline \multicolumn{4}{|l|}{5} \\
\hline
\end{tabular}

Table 4. Effect of different gamma irradiation doses on lipid content (\%), biomass, and lipid productivity ( $\mathrm{mg} / \mathrm{L}$ day) of Chlamydomonas sp. after a cultivation period of 15 days

\begin{tabular}{|c|c|c|c|c|}
\hline & $\begin{array}{c}\text { Irradiation dose } \\
\text { (Gy) }\end{array}$ & $\begin{array}{l}\text { Lipid content }^{1} \\
(\%)\end{array}$ & $\begin{array}{c}\text { Biomass productivity }{ }^{2} \\
\text { (mg/L day) }\end{array}$ & $\begin{array}{l}\text { Lipid productivity }{ }^{3} \\
\text { (mg/L day) }\end{array}$ \\
\hline & 0 & $23.4 \pm 0.4^{\mathrm{b}}$ & $84.5 \pm 2.1^{\mathrm{a}}$ & $19.8 \pm 1.0^{\mathrm{b}}$ \\
\hline & 25 & $27.3 \pm 1.2^{\mathrm{a}}$ & $78.2 \pm 0.9^{b}$ & $21.3 \pm 0.3^{a}$ \\
\hline & 50 & $21.2 \pm 1.0^{\mathrm{d}}$ & $73.1 \pm 1.6^{c}$ & $15.5 \pm 1.4^{\mathrm{c}}$ \\
\hline & 75 & $22.1 \pm 0.8^{c}$ & $68.6 \pm 0.4^{d}$ & $15.2 \pm 0.5^{\mathrm{c}}$ \\
\hline & 100 & $22.0 \pm 0.3^{c}$ & $65.3 \pm 0.5^{\mathrm{e}}$ & $14.4 \pm 1.8^{\mathrm{d}}$ \\
\hline & 200 & $21.5 \pm 0.6^{\mathrm{d}}$ & $63.6 \pm 0.7^{f}$ & $13.7 \pm 0.8^{e}$ \\
\hline & 300 & $18.1 \pm 0.5^{\mathrm{e}}$ & $61.2 \pm 1.3^{\mathrm{g}}$ & $11.1 \pm 2.0^{f}$ \\
\hline \multicolumn{5}{|c|}{$\begin{array}{ll}1 & \mathrm{C}_{\text {Lipid }}=[\text { Lipid } \text { weight } \div \text { Biomass } \text { concentration }] \times 100\end{array}$} \\
\hline \multicolumn{5}{|c|}{$2 \quad \mathrm{P}$ Biomass $=$ Biomass concentration $\div$ Cultivation period } \\
\hline \multicolumn{5}{|c|}{$3 \quad \mathrm{P}_{\text {Lipid }}=[\mathrm{C}$ Lipids $\times \mathrm{P}$ biomass $] \div 100$} \\
\hline \multicolumn{5}{|c|}{4 Data were expressed as means \pm S.D., $n=3$} \\
\hline \multicolumn{5}{|c|}{ Values with the same letter(s) are insignificantly different at $p$-value $<0.05$ (Tukey's HSD test). } \\
\hline
\end{tabular}




\section{Conclusion}

The current study has aimed to explore the influence of gamma irradiation treatment on the production of biomass and lipids of three green microalgae; S. ecornis, S. communis, and Chlamydomonas sp. Results showed that gamma irradiation has significantly increased the $S$. ecornis growth, as irradiation dose increases, while having a negative effect on the growth of both S. communis and Chlamydomonas sp. Consequently, the content of lipid, and thus lipid productivity of $S$. ecornis also increased with an increase of gamma irradiation. On the other hand, the non-irradiated culture of S. communis has recorded higher yields of lipid content, biomass, and lipid productivity more than the gamma-irradiated culture of the same microalga. Conversely, lipid content and productivity of Chlamydomonas $\mathrm{sp}$. increased when algae were irradiated at $25 \mathrm{~Gy}$, then decreased as the dose increased. Further efforts should be made to isolate mutants with high lipid productivity for biodiesel production at industrial scale.

\section{References}

Abomohra, AE; El-Shouny, W; Sharaf M; Abo-Eleneen, M (2016) Effect of gamma radiation on growth and metabolic activities of Arthrospira platensis. Braz Arch Biol Technol 59, e16150476.

Abo-State, AM; Shanab SMM; Ali, HEA (2019) Effect of nutrients and gamma radiation on growth and lipid accumulation of Chlorella vulgaris for biodiesel production. J Radiat Res Appl Sci 12, 332-342.

Afify, AMR; Rashed, MM; Ebtesam, AM; El-Beltagi, HS (2013) Effect of gamma radiation on the lipid profiles of soybean, peanut and sesame seed oils. Grasas Aceites 64, 356-368.

Agarwal, R; Rane, SS; Sainis JK (2008) Effects of (60) Co gamma radiation on thylakoid membrane functions in Anacystis nidulans. J Photoch Photobio B 91, 9-19.

Axelsson, M; Gentili, F (2014) A Single-step method for rapid extraction of total lipids from green microalgae. PLOS ONE 9, e89643.

Cheng, J; Huang, Y; Feng, J; Sun, J; Zhou, J; Cen, K (2014) Mutate Chlorella sp. by nuclear irradiation to fix high concentration of $\mathrm{CO}_{2}$. Bioresour Technol 136, 496-501.
Choi, J; Yoon, M; Joe, M; Park, H; Lee, SG; Han, SJ; Lee, PC (2014) Development of microalga Scenedesmus dimorphus mutant with higher lipid content by radiation breeding. Bioprocess Biosyst Eng 37, 2437-2444.

Dallas, LJ; Keith-Roach, M; Lyons, BP; Lyons, BP; Jha, AN (2012) Assessing the impact of ionizing radiation on aquatic invertebrates: A critical review. Radiat Res 177, 693-716.

Ermavitalinia, D; Sari, IP; Prasetyo, EN; Abdulgani, $\mathrm{N}$; Saputro, TB (2017) Effect of gamma 60Co irradiation on the lipid content and fatty acid composition of Nannochloropsis sp. microalgae. AIP Conference Proceedings 1854, 020009.

Fuma, S; Ishii, N; Takeda, H; Miyamoto, K; Yanagisawa, K; Doi, K; Kawaguchi, I; Tanaka, N; Inamori, Y; Polikarpov, GG (2009) Effects of acute Y-irradiation on the aquatic microbial microcosm in comparison with chemicals. J Environ Radioact 100, 10271033.

Garay, LA; Boundy-Mills, KL; German, JB (2014) Accumulation of high-value lipids in single-cell microorganisms: A mechanistic approach and future perspectives. J Agr Food Chem 62, 2709-2727.

Golz, AL; Bradshaw, C (2019) Gamma radiation induced changes in the biochemical composition of aquatic primary producers and their effect on grazers. Front Environ Sci 7, 100.

Griffiths, MJ; Harrison, STL (2009) Lipid productivity as a key characteristic for choosing algal species for biodiesel production. J Appl Phycol 21, 493-507.

Guillard, R; Lorenzen, C (1972) Yellow green algae with Chlorophyllide C. J Appl Phycol 8, 10-14.

Jan, S; Parween, T; Siddiqi, TO; Mahmooduzzafar, M (2012) Effect of gamma radiation on morphological, biochemical, and physiological aspects of plants and plant products. Environ Rev 20, 17-39.

Jeong, MA; Jeong, RD (2018) Applications of ionizing radiation for the control of postharvest diseases in fresh produce: recent advances. Plant Pathol 67, 18-29.

Khan, MI; Shin, JH; Kim, JD (2018) The promising future of microalgae: Current status, challenges, and optimization of a sustainable and renewable industry for biofuels, feed, and other products. Microb Cell Fact 17, 36.

Kovács, E; Keresztes. Á (2002) Effect of gamma and UV-B/C radiation on plant cells. Micron 33, 199210. 
Lari Z; Moradi-kheibari, $\mathrm{N}$; Ahmadzadeh, $\mathrm{H}$; Abrishamchi, P; Moheimani, NR; Murry, MA (2016) Bioprocess engineering of microalgae to optimize lipid production through nutrient management. $J$ Appl Phycol 28, 3235-3250.

Liu, B; Ma, C; Xiao, R; Xing, D; Ren, H; Ren, N (2015) The screening of microalgae mutant strain Scenedesmus sp. Z-4 with a rich lipid content obtained by $60 \mathrm{Co}$ Y-ray mutation. RSC Adv 5, 5205752061.

Medipally, SR; Yusoff, FMd; Banerjee, S; Shariff, M (2015) Microalgae as sustainable renewable energy feedstock for biofuel production. BioMed Res Int pp 1-13.

Mohajer, S; Taha, RM; Lay, MM; Esmaeili, AK; Khalili, M (2014) Stimulatory effects of gamma irradiation on phytochemical properties, mitotic behavior and nutritional composition of Sainfoin (Onobrychis viciifolia Scop.). Sci World J 854093.

Pal-Nath, D; Khozin-Goldberg, I; Cohen, Z Boussiba, S (2011) The effect of light, salinity, and nitrogen availability on lipid production by Nannochloropsis sp. Appl Microbiol Biotechnol 90, 14291441.

Qari, H; Rehan, M; Nizami, AS (2017) Key issues in microalgae biofuels: A short review. Energy Procedia 142, 898-903.

Rahman, DY; Rachmayati, R; Widyaningrum, DN; Susilaningsih, D (2020) Enhancement of lipid production of Chlorella sp. 042 by mutagenesis. IOP Conf Ser Earth Environ Sci 439, 012021.
Raja, R; Coelho, A; Hemaiswarya, S; Kumar, P; Carvalho, I; Alagarsamy, A (2018) Applications of microalgal paste and powder as food and feed: An update using text mining tool. Beni-Suef Univ $J$ Basic Appl Sci 7, 740-747.

Rawat, I; Ranjith Kumar, R; Mutanda, T; Bux, F (2011) Dual role of microalgae: Phytoremediation of domestic wastewater and biomass production for sustainable biofuels production. Appl Energy 88, 3411-3424.

Sibi, G; Shetty, V; Mokashi, K (2016) Enhanced lipid productivity approaches in microalgae as an alternative for fossil fuels-A review. J Energy Inst 89, 330-334

Tale, MP; Devi Singh, R; Kapadnis, BP; Ghosh, SB (2018) Effect of gamma irradiation on lipid accumulation and expression of regulatory genes involved in lipid biosynthesis in Chlorella sp. J Appl Phycol 30, 277-286

Williams, PJL; Laurens, LML (2010) Microalgae as biodiesel \& biomass feedstocks: Review \& analysis of the biochemistry, energetics \& economics. Energy Environ Sci 3, 554-590.

Yang, F; Hanna, M; Sun, R (2012) Value-added uses for crude glycerol - A byproduct of biodiesel production. Biotech Biofuels 5, 2-10.

Zhu, LD; Li, ZH; Hiltunen, E (2016) Strategies for lipid production improvement in microalgae as a biodiesel feedstock. BioMed Res Int pp 1-8. 


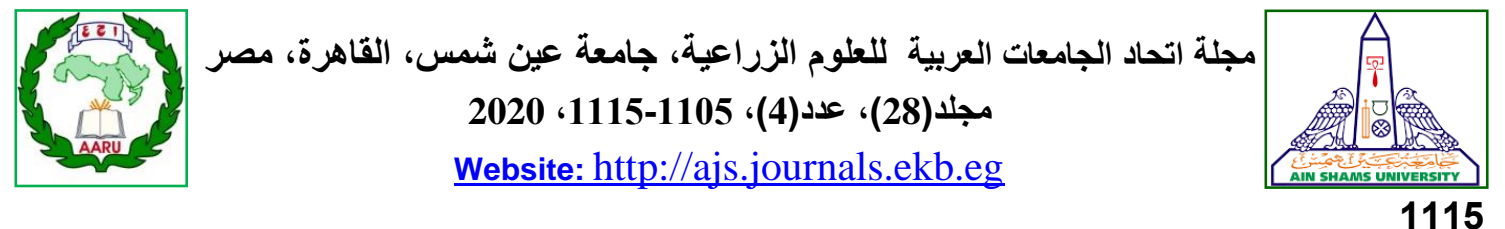

تأثير التثعيع الجامى على نمو وإنتاجية الدهون في الطحالب الخضراء الدقيقـة

[78]

مروة محمد موسى 1" - ميرفت على محمد أبو ستيت1 - أحمد عبدالوهاب محمد عبد الحافظ2 1- قسم الميكروبيولوجيا الإثعاعية - المركز القومي لبحوث وتكنولوجيا الاشعاع - هيئة الطاقة الذرية المصرية - صدئ.

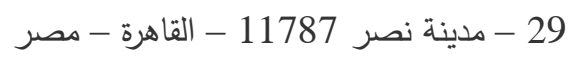

2- قسم الميكروبيولوجيا الزراعية - كلية الزراعة - جامعة عين شمس - ص.ب. 68 - حدائق شبرا 11241- القاهرة -

*Corresponding author: marwa.moussa@agr.asu.edu.eg

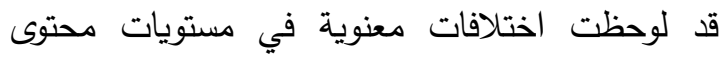

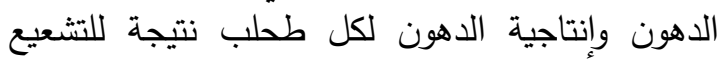
الجامى. حيث كانت أعلى نسبة لمحتوى وإنتاجية الدهون

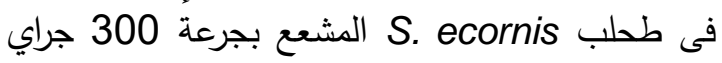

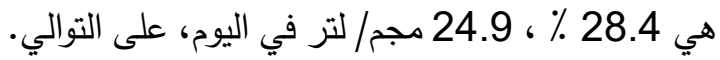

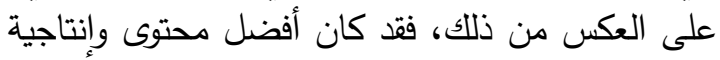

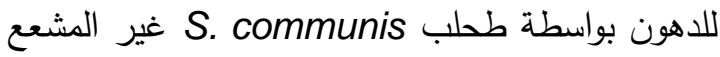
(24.4 ٪ ، 16.6 مجم/ لتر فى اليوم) مقارنة بالمزارع المشععة بغض النظر عن جرعة التشعيع المستخدمة. لمعارنة باليزاع. وتم الحصول على أفضل محتوى وإنتاجية للدهون

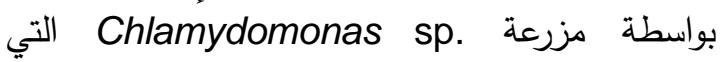
عرضت لجرعة 25 جراي (27.3 ٪ ، كرعة ، 21.3 مجم/ لتر التر في اليوم). وفي الختام، فقد أشارت النتائج إلى أن أن

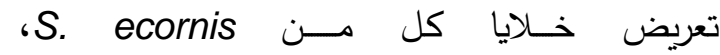

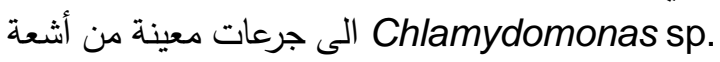

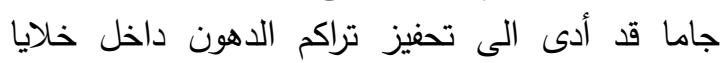

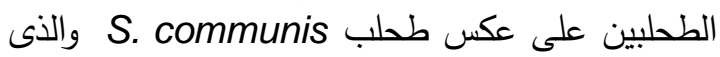
تأثر بشكل سلبى بعد تعرضه للتشعيع الجامى.

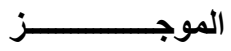

في هذا البحث تمت دراسة تأثير تعريض مزرعة كل

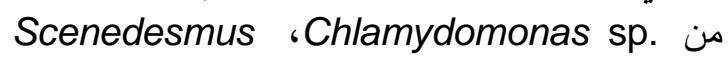
S. communis، ecornis على النمو وإنتاجية الدهون. وتم تقدير تركيز الكتلة

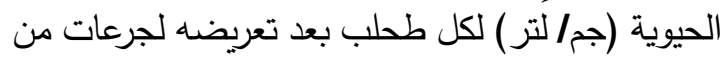

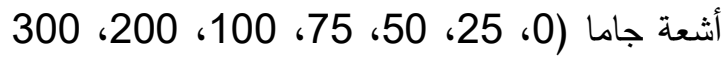

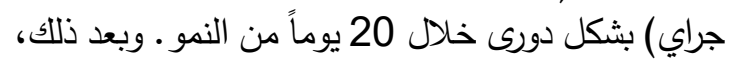

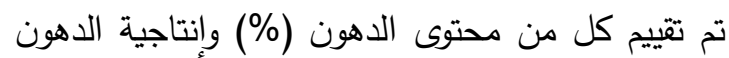

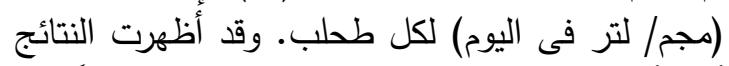

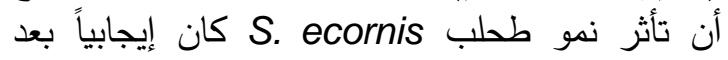

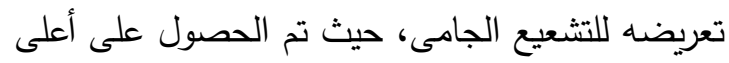

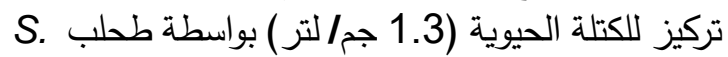

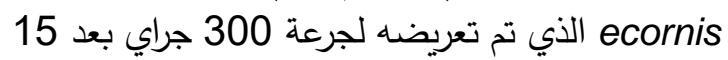

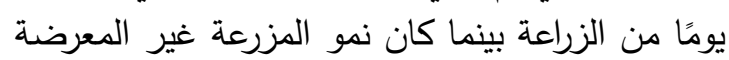

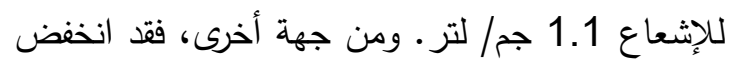

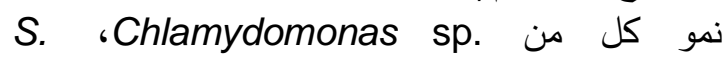
communis 